\title{
Prymas Hlond o ustroju politycznym powojennej Polski
}

Prymas Polski kard. August Hlond miał zwyczaj odręcznego sporządzania notatek na kartach czy nawet skrawkach papieru. Zapisywał swoje refleksje na kanwie aktualnych spraw oraz celniejsze - jego zdaniem - myśli i fakty z przeczytanych dzieł. Czynił to przede wszystkim w czasie II wojny światowej, gdy przebywał na emigracji we Francji w latach 1940-1944. Ogromna część tych notatek dotyczyła wizji powojennego odrodzenia Kościoła i Europy, a zwłaszcza nowej, odrodzonej Polski. Wiele notatek prymasa ma charakter ustrojowo-polityczno-moralny. Część to postulaty, mniej lub bardziej konkretne, rozwiązań ustrojowych, inne - tych jest znacznie więcej - to uwagi na temat zasad i sposobu sprawowania władzy przez rządzących, które bardzo często zawierają ostrą krytykę poprzednich rządów, zwłaszcza sanacyjnych.

Notatki kard. Hlonda przepisał w latach 70. i 80. z oryginałów ks. Stanisław Kosiński, salezjanin, i umieścił w swoim monumentalnym dziele Acta Hlondiana (oryginały notatek znajdują się obecnie w Archiwum Archidiecezjalnym w Gnieźnie) $)^{1}$. Z kolei ks. Wojciech Necel, chrystusowiec, znaczną część wspomnianych notatek opublikował w książce $Z$ notatnika Kardynała Augusta Hlonda ${ }^{2}$. Nie jest to jednak publikacja naukowo-krytyczna, a popularyzatorska, historyczno-duszpasterska, w której m.in. pominięto większość notatek dotyczących ustroju politycznego.

Niniejszy artykuł nie omawia wszystkich notatek kard. Hlonda na temat nowej, powojennej Polski ${ }^{3}$. Przedstawia tylko zapiski traktujące o przyszłym ustroju politycznym państwa ${ }^{4}$.

${ }^{1}$ Acta Hlondiana. Materiały do życia i działalności kardynała Augusta Hlonda prymasa Polski. Zebrał ks. St. Kosiński, Ląd nad Wartą 1966-1991, t. III, cz. 2, 7, 9-13, mpis (cyt. dalej AH). Być może w spuściźnie kard. Hlonda, która nie jest scalona i opracowana, znajdą się dalsze jego noty.

${ }^{2}$ [A. Hlond] Z notatnika Kardynata Augusta Hlonda. Opr. W. Necel, Poznań 1995 (cyt. dalej A. Hlond, $Z$ notatnika).

${ }^{3}$ Artykuł jest rozszerzoną wersją referatu wygłoszonego na międzynarodowej sesji naukowej Prymas Polski August Hlond: pasterz ,, z głęboka perspektywa w dal”, która odbyła się na Uniwersytecie Papieskim Jana Pawła II w Krakowie w dniu 30 III 2012 r.

${ }^{4}$ Notatki na temat powojennej Polski ogólnie omówili: P. Bortkiewicz, Myślenie wedtug praw$d y$ i wiary, w: A. Hlond, Z notatnika, s. 15-21 oraz T. Serwatka, Koncepcje społeczno-polityczne 
I. Nowa konstytucja i jej zasady. Kard. Hlond wierzył, że skutkiem II wojny światowej będzie totalne odrodzenie Europy, przede wszystkim duchowe, w którym Polska odegra decydującą rolę. Dlatego powojenna nowa Polska musi być zbudowana na nowych podstawach, w tym także w dziedzinie ustrojowo-politycznej: „Nowa koncepcja Polski - może i nowa konstytucja"5. Krytycznie oceniał przedwojenne konstytucje Polski, tak marcową z 1921, jak kwietniową z 1935 r., a przede wszystkim stosunki polityczne i sposób rządzenia w państwie. Uważał, że obie konstytucje ,pisano nie dla narodu i jego dobra, lecz przeciw komuś lub dla kogoś”. Jego zdaniem, Polska od 1918 do 1939 r. szukała swojej ,formy państwowej i swego rządu” i ich nie znalazła, ponieważ ,nie znalazła jedności ducha - była duchowo rozbita i zatruta jadami, na które Europa chorowała". Dwudziestolecie to chwile nieładu, organizowania, buntu, zamachów, gorączki, a rządy sanacji pogarszały chorobę. Naród nabrał wstrętu do państwa, bo państwo zdawało się sprzeciwiać dobru ogółu, zamiast porządku wytwarzało nieład, sprzyjało dekadencji, sprowadzało zubożenie, zakuwało w niewolę ${ }^{6}$ Największą krzywdą ustrojową, jaką państwu wyrządzono, było wydanie na łup partii i wewnętrznych sporów parlamentu i rządów. To dało partiom władzę nad narodem i nad państwem. Sprawy i walki partyjne zalegalizowano i toczono je z nieograniczoną namiętnością, spychając interesy i dobro państwa na miejsce podrzędne. Nie chodziło o państwo, chodziło o władzę w państwie. To zabiło państwo i jego autorytet ${ }^{7}$.

Prymas swoje uwagi ustrojowe, skreślone podczas wojny, traktował jako sugestie bądź wytyczne do projektu nowej konstytucji, który to projekt - jak sądził - winien przygotować i opracować po wojnie rząd tymczasowy (prowizoryczny) w kraju i to w ciągu 2 lat. W tym okresie rząd miał także przygotować nowe prawo wyborcze, przeprowadzić nowe wybory do sejmu i senatu ${ }^{8}$.

$\mathrm{Na}$ temat trybu uchwalenia konstytucji prymas się nie wypowiedział. Natomiast poczynił kilka uwag pod adresem przyszłych autorów projektu konstytucji. Radził, aby nie budowano ,ustroju i życia na zawsze lub na ty-

Prymasa Polski Augusta Hlonda (1926-1948), Poznań 2006, s. 128-136, bardziej szczegółowo, ale tylko częściowo: J.M. Roth [J. Konieczny], Społeczno-polityczna działalność prymasa Polski Augusta Hlonda w latach 1939-1945, Toruń 2009, s. 307-341. Natomiast pomysły ustrojowe kard. Hlonda przedstawił jako pierwszy: K. Krasowski, Zasady konstytucji Rzeczypospolitej Polskiej prymasa Augusta Hlonda z lat 1940-1944, w: Ustrój i prawo w przeszłości dalszej i bliższej. Studia historyczne o prawie dedykowane prof. Stanisławowi Grodziskiemu w pięćdziesiąta rocznice pracy naukowej. Praca zbiorowa pod red. J. Malca i W. Uruszczaka, Kraków 2001, s. 275-290. Artykuł K. Krasowskiego, zapewne z racji elitarnego wydawnictwa, w jakim został zamieszczony, nie został zauważony ani przez T. Serwatkę, ani J.M. Rotha. W stosunku do artykułu K. Krasowskiego w niniejszym artykule przedstawiono niektóre zagadnienia obszerniej oraz dodano nowe.

${ }^{5}$ A. Hlond, Z notatnika, s. 300.

${ }^{6}$ Ibidem, s. 142, 150, 171, 300.

${ }^{7} \mathrm{AH}, \mathrm{III} / 13, \mathrm{k} .173$.

${ }^{8}$ A. Hlond, Z notatnika, s. 168, 169, 192. 
siąclecie, lub nawet na jedno stulecie". Należy dać dobre państwo obecnemu pokoleniu; następne pokolenia konstytucję rozwiną i uzupełnią lub zmienią stosownie do potrzeb. Każdy ustrój, nawet najlepszy w momencie powstania, może być dobry tylko pewien czas, potem zmiany warunków będą wymagały poprawek, może nawet rewolucji. „Konserwatyzm ustrojowy jest szkodliwy, bo thumi, jest uporem w formie"9. Ustawa zasadnicza musi być poddana rewizji co pewien czas, ale bez wstrząsów ${ }^{10}$.

Konstytucji nie należy improwizować; powinna ona wynikać z ducha i tradycji narodu, z jego warunków i potrzeb. „Forma rządu ma być taka, jak w tej chwili najbardziej odpowiada potrzebom narodu; może się zmieniać i niekiedy trzeba $\mathrm{z}$ monarchii zrobić republikę i odwrotnie; chwilowo może być konieczna dyktatura"11.

Chodziło mu nie tylko o wybór „polityki i rządu”, ale „zasady moralnej, stałej i pewnej" państwa. Nowa Polska musi być chrześcijańska jako państwo ${ }^{12}$. Jej konstytucja owiana duchem chrześcijańskim, „nie uciekająca przed nazwą Stwórcy". (Konstytucja kwietniowa z 1935 r. nie zawierała preambuły z odwołaniem się do Boga, która była w poprzedniej Konstytucji marcowej z 1921 r.). Godłem nowej Polskiej ma być orzeł z przywróconym krzyżem w koronie (krzyż w koronie był w godle Polski w latach 1919-1927) ${ }^{13}$. Konstytucja gwarantuje prawo obywateli do wolności religijnej, ale nie absolutnej. „Jedną z zasad państwa chrześcijańskiego jest swoboda wyznania, bo wiara nie jest z przymusu; ta swoboda nie oznacza swobody praktyk niezgodnych z moralnością i ustawami ani agitacji religijnej zagrażającej spokojowi publicznemu ${ }^{14}$.

Nowa konstytucja ma być światła, społeczna, zapewniająca państwu ład, suwerenność, prestiż, autorytet ${ }^{15}$. „Z narodu i państwa musi uróść Rzeczpospolita jako własność duchowa wszystkich obywateli” ${ }^{16}$. „Z ludu trzeba zrobić naród; zaprowadzić poczucie jedności, państwowości, karności, wyraźnego stanu prawnego, celowej organizacji, ogólnych zasad współżycia, trzeba skupić wszystkich wobec jednej idei”"17. Powinno się wykluczyć czynniki dezintegracji narodu i państwa. Stąd wolność stowarzyszeń nie powinna dotyczyć takich, które 1) rozsadzają zwartość państwa, 2) są szkodliwe dla struktury

${ }^{9}$ A. Hlond, Z notatnika, s. 150, 210. Przedwojenne poglądy kard. Hlonda na ustrój państwa przedstawili: K. Krasowski, Biskupi katoliccy II Rzeczypospolitej. Stownik biograficzny, Poznań 1996, s. 88-91, powtórzył w cyt. artykule Zasady konstytucji, s. 277-280 oraz ostatnio T. Serwatka, op. cit. s.43-57.

${ }^{10} \mathrm{AH}, \mathrm{III} / 13, \mathrm{k} .245$.

${ }^{11}$ A. Hlond, Z notatnika, s. 187, 193, 301.

${ }^{12}$ Ibidem, s. 146, 147, 193, 278.

${ }^{13}$ Ibidem, s. 128, 136, 193, 252; AH III/12, k. 225.

${ }^{14}$ A. Hlond, $Z$ notatnika, s. 311 .

${ }^{15}$ Ibidem, s. 300.

${ }^{16}$ Ibidem, s. 147.

${ }^{17}$ Ibidem, s. 163. 
społecznej państwa, 3) są zbyteczne z racji bezwartościowego partykularyzmu, 4) mają zastępować niedozwolone partie czy zrzeszenia, 5) są wykładnikami kierunków myślowych szkodliwych dla państwa i jego ducha, 6) tajne ${ }^{18}$.

Kard. Hlond twierdził, że to przede wszystkim partie polityczne nie koncentrują narodu, lecz rozbijają go i są przeżytkiem z ,arsenału rupieci” XIX wieku ${ }^{19}$. Zastanawiał się, czy w nowej Polsce winny działać partie czy monopartia, a może korporacje zawodowe? W każdym razie partie o celach i programach przeciwnych konstytucji nie powinny być tolerowane. To znów skłaniał się do zastąpienia partii politycznych korporacjami zawodowymi ${ }^{20}$. Argumentował już przed wojną: „Jednostka ma mieć udział czynny w sprawach państwowych, choćby przez reprezentację stanową (korporacjonizm), zdrowszą od geograficznej, przypadkowej, partyjnej" ${ }^{21}$. Absolutnie był za wykluczeniem masonów od sprawowania funkcji publicznych, nie tylko jako członków organizacji tajnej, ale wrogiej i szkodliwej: „Masoneria pracowała przez 20 lat przeciw narodowi i Kościołowi [...] chciała być w Polsce nad państwem [...] wykonywała dyktaturę ukrytą, bezwzględną"22.

Prymas nie kwestionował zasady demokracji. W jednym z listów do bliskiego mu Bogusława Longchampsa de Berier (znanego lwowskiego adwokata przebywającego na wojennej emigracji w Lyonie) wyznał, że pragnie, aby ustrój przyszłej Polski był ,naprawdę demokratyczny, taki iżby organizacji państwowej zapewnił twórczą współpracę narodu, a zarazem ustrzegł Rzeczpospolitą od błędów, od których Europa ginie"23. Natomiast w notatkach napisał: „Demokracja to słuszny dział narodu w funkcjach państwowych”. Zwracał jednak uwagę na częste jej nadużywanie i wynaturzenie: „Demokracja i parlament to niekoniecznie postęp, bo mogą prowadzić do upadku"24. Stąd był przekonany, że „władzy nie może wykonywać masa, lecz małe grono ludzi kompetentnych; musi być hierarchia i elita" 25 . We władzach musi być jasny podział zadań i respektowanie kompetencji. Władza wykonawcza musi być personalna, nie kolektywna; połączona $\mathrm{z}$ odpowiedzialnością osobistą a nie zbiorową. Natomiast ciała doradcze i ustawodawcze mogą być zbiorowe. Rządy ludu i rad są szkodliwe i chaotyczne ${ }^{26}$.

Przytoczone powyżej niektóre zasady ustrojowe sformułowane przez kard. Hlonda pozwalają lepiej zrozumieć jego wizję ustroju politycznego powojennej Polski.

\footnotetext{
${ }^{18}$ Ibidem, s. 177.

${ }^{19}$ A. Hlond, Z notatnika, s.144.

${ }^{20}$ Ibidem, s. 182, 300; AH III/13, k. 245.

${ }^{21}$ A. Hlond, Z notatnika, s. 35.

${ }^{22}$ Ibidem, s. 256, 257.

${ }^{23}$ A. Hlond do B. Longchampsa 12 VIII 1941, AH IV/17, k. 15-16.

${ }^{24} \mathrm{AH}, \mathrm{III} / 13, \mathrm{k} .224$.

${ }^{25}$ AH III/13, k. 223; A. Hlond, Z notatnika, s. 190.

${ }^{26}$ AH III/13, k. 196; A. Hlond, Z notatnika, s. 187.
} 
II. Król, jego uprawnienia. Kard. Hlond początkowo nie wykluczał zachowania w powojennej Polsce republikańskiej formy ustroju. Zapisał bowiem: „W Polsce musi być i będzie albo demokratyczny prezydent, albo król demokratyczny" ${ }^{27}$. Niebawem doszedł do wniosku, że najlepszym rozwiązaniem ustrojowym dla powojennej Polski byłoby przywrócenie monarchii ${ }^{28}$. W sierpniu $1941 \mathrm{r}$. w liście do B. Longchampsa napisał: [...] trzeba będzie koniecznie dać Polsce króla, ale króla nowoczesnego"29. Miał świadomość, że istnieją różne racje przeciwne przywróceniu monarchii, zwłaszcza monarchii dziedzicznej. W Polsce jednak - napisał w notatkach - silniejsze są racje za monarchią: „nasz klimat w tej chwili domaga się Króla”30.

Wymienił kilka powodów za przywróceniem monarchii. Prezydent Republiki jest człowiekiem tej partii, która go większością głosów wybiera i tym samym jest przeciwnikiem ludzi innych partii, natomiast głowa państwa powinna być ponad sprawami partyjnymi i nie być dla nikogo przeciwnikiem. Król niepochodzący z wyborów politycznych ma dostojność wynoszącą go ponad kłótnie parlamentarne. Nadto stwierdził: „Nie mieliśmy szczęścia do prezydentów; Opatrzność ich przekreśliła”. Trzeba więc odwołać się do idei piastowskiej i wawelskiej, czyli królewskiej. Król skupi i scali naród, zaradzi upadkowi autorytetu państwa. Będzie najistotniejszym wyrazem jedności i odrodzenia. „Nic nie wyraża tak wolności Polski jak monarchia i korona”. Wskrzesi dynamizm Chrobrych i Sobieskich. Da Polsce i jej idei państwowej ciągłość dziejową w Europie. Nadto Polska, by oddziaływać należycie na bliskie narody, musi się przyoblec w majestat królewski - inaczej nie będzie miała należytej atrakcji. Dlatego erę nowej Polski „musimy zacząć rozwiązaniem ostatecznym i totalnym - Królestwem. Połowiczne formy nie załatwią sprawy, nie wyzwolą pełni naszego ducha" 31 .

Kard. Hlond poczynił także uwagę, że w monarchii trudniej niż w republice wprowadzić dyktaturę i totalitaryzm (niewątpliwie miał na myśli republikańskie Niemcy, w których powstała dyktatura hitlerowska). Poza tym monarchia dzisiejsza musi mieć „,z konieczności dziejowej” charakter demokratyczny co do ducha, ustroju i form. Przyszłą monarchię w Polsce określił jako „ludową"32.

${ }^{27}$ A. Hlond, Z notatnika, s. 299.

${ }^{28}$ K. Krasowski twierdzi, że już przed 1939 r. zauważalne były u kard. Hlonda „wyraźne sympatie dla systemu klasycznej monarchii” i wynikały one zapewne z faktu, że głównym jego doradcą politycznym był prof. Stefan Dąbrowski, przewodniczący Głównego Zjednoczenia Monarchistów (Zasady konstytucji, s. 285). Owe „wyraźne sympatie” i domniemany wpływ prof. Dąbrowskiego trudno jednak potwierdzić źródłowo. Natomiast znany był u kard. Hlond wielki kult Chrystusa Króla i Królestwa Chrystusowego (zob. J. Pietrzak, Petnia prymasostwa. Ostatnie lata prymasa Polski kardynała Augusta Hlonda 1945-1948, Poznań 2009, t. I, s. 366-367.

${ }^{29}$ A. Hlond do B. Longchampsa 12 VIII 1941, AH IV/17, k. 15-16.

${ }^{30} \mathrm{AH} \mathrm{III/13,} \mathrm{k.} 186$.

${ }^{31}$ AH III/12, k. 224; AH III/13, k. 173, 186-189, 192.

${ }^{32}$ AH III/13, k. 187, 192, 194. 
„Instytucja króla i dobry ustrój nie dadzą pierwszeństwa ani arystokracji ani demokracji w znaczeniu tej i owej grupy, ale narodowi, bo każdy będzie mógł być nawet królem, jeżeli osobistymi wartościami swymi się na to będzie kwalifikował. Innych kwalifikacji nie będzie, ani rodowych, ani tradycyjnych, ani stanowych $^{33}$. W innym miejscu napisał o nowej Polsce: „Najbardziej (demokratyczne) ludowe Królestwo a zarazem najbardziej autorytatywna demokracja - w nowym historycznym stylu - Rzeczpospolita"34.

Zakres władzy królewskiej miał być szerszy niż w czasach przedrozbiorowych. „Król w dawnej Polsce miał mniej praw niż Prezydent Rzeczypospolitej na mocy ostatniej konstytucji. To było zgubne. [...] Król nosił koronę, nie miał autorytetu swej władzy"35. Kard. Hlond pozycję monarchy w nowej Polski określił następująco: „Król - źródło wszelkiej władzy w Państwie; właściwy szef wszystkiego, ale bezpośrednio działa tylko w sprawach określonych konstytucją; w innych przez konstytucyjne organy". Monarcha miał być czynnikiem nadrzędnym tak w stosunku do parlamentu, jak i rządu: „Sejm nie nad rządem, bo rząd rządem, nad rządem tylko król, ale i rząd nie nad Sejmem, bo i nad Sejmem tylko król”. W innym miejscu nazwał króla ,szczytowym czynnikiem ładu w Rzeczypospolitej” oraz „czynnikiem naczelnym równowagi wewnętrznej w kraju" ${ }^{36}$. Na temat konkretnych prerogatyw królewskich napisał jednak niewiele. Podkreślił tylko, że monarcha powinien mieć prawo swobodnego mianowania i odwoływania premiera i ministrów: „Król może dać dymisje całemu rządowi, ale także poszczególnym ministrom, zastępując ich innymi $[\ldots]$. To król daje narodowi rząd"37. Zatem zakres władzy królewskiej byłby przynajmniej taki, jaki posiadał prezydent Rzeczypospolitej na podstawie Konstytucji kwietniowej.

Prezydent Rzeczypospolitej według wspomnianej konstytucji był odpowiedzialny tylko ,przed Bogiem i historią”. Kard. Hlond w tej materii napisał tylko: „Król musi być karny nie tylko wobec konstytucji, ale także w używaniu swej władzy, w objawianiu swego autorytetu" ${ }^{38}$. Czy myślał o odpowiedzialności prawnej, czy tylko nakazie moralnym - nie wiadomo.

III. Elekcja króla, rodzina królewska. Początkowo kard. Hlond nie wykluczał zaprowadzenia tronu dziedzicznego. Świadczy o tym notatka dotycząca pierwszego króla: „Królestwo od zaraz, by nie tracić czasu na provisoria. Interrex jak najrychlej przedstawi narodowi kandydata króla. $Z$ rodziną królewską pakt na $1 / 5$ wieku, poczem [na] dalsze $1 / 2$ w., o ile naród [paktu] nie

\footnotetext{
${ }^{33} \mathrm{AH} \mathrm{III/12,} \mathrm{k.} 227$.

${ }^{34}$ AH III/13, k. 195-196.

${ }^{35}$ AH III/13, k. 186-187.

${ }^{36}$ AH III/13, k. 180, 190,191, 196.

${ }^{37}$ AH III/12, k. 227; A. Hlond, Z notatnika, s. 178.

${ }^{38} \mathrm{AH}$ III/13, k. 191.
} 
wypowie" 39 . Nadto ten pierwszy król winien zaimponować Polsce i Europie, zwłaszcza krajom, które ,gotowe są przy nim się skupić”, czyli utworzyć federację z Polską ${ }^{40}$. Nie wiadomo, w jaki sposób kandydat desygnowany przez interreksa miał być wybrany na króla ani jaka miała być treść ,paktu” z dynastią i w jakim trybie miał być on zawarty oraz z jakich powodów naród mógł umowę wypowiedzieć. W każdym razie wspomniana notatka przywodzi na pamięć historyczne pacta conventa oraz zasadę elekcji dynastii przewidzianą przez Konstytucję 3 maja.

Wkrótce jednak kard. Hlond odszedł od zasady dziedziczności na rzecz elekcyjności tronu. W zapiskach podał kilka argumentów przeciw dziedziczności:

- najwyższa władza w Rzeczypospolitej nie może być prawem jednej rodziny, bo takie prawo nie ma ani w sobie, ani w warunkach polskich żadnego uzasadnienia ${ }^{41}$,

- nie można szczęścia, bezpieczeństwa i całości narodu oraz państwa narażać na niepewność losu przez dynastię dziedziczną ${ }^{42}$,

- żadna rodzina nie może dać gwarancji, że jej potomkowie będą moralnie, intelektualnie, fizycznie zdolni rządzić; rody królewskie męczą się i degenerują ${ }^{43}$,

- w przypadku tronu dziedzicznego istnieje „,wielkie ryzyko i szkodliwe następstwa także możliwych regencji za małoletniego króla lub niezdolnego" 44 ,

- elekcje królewskie w Polsce nie były złe w sobie, lecz w sposobie ich odbywania: „Dały przecież Batorego, Sobieskiego" 45 ,

- dobra elekcja króla uchroni kraj od szkód polityki dynastycznej, która nieraz wciągała kraj w zamieszki i wojny ${ }^{46}$.

Zapiski kard. Hlonda dotyczące elekcji króla są dość szczegółowe. Wybór miał być oparty na idei „nowoczesnej selekcji” i wzorować się na starodawnej, sprawdzonej i ,pożytecznej” elekcji papieża dokonywanej przez konklawe kardynałów (kolegium kardynalskie od papieża Sykstusa V mogło liczyć nie więcej jak 70 kardynałów) ${ }^{47}$. Napisał nawet, że wyboru króla winno do-

${ }^{39} \mathrm{AH} \mathrm{III} / 13$, k. 212.

${ }^{40} \mathrm{AH} \mathrm{III/13,} \mathrm{k.} 192$.

${ }^{41}$ AH III/12, k. 226.

${ }^{42}$ AH III/13, k. 196.

${ }^{43}$ AH III/12, k. 226; AH III/13, k. 194; „Następca tronu, wiedząc że będzie królem, żyje w fałszywej atmosferze, sytuacji nieżyciowej fałszującej duszę, oddalającej go od kontaktu z rzeczywistością, poza tym jest ryzyko degeneracja, atawizm, nieudanie się królewicza - co tak często pogrążało narodu w nieszczęściu; syn burzył wspaniałe czyny i chwałę ojca, dziada" (AH III/13, k. 195).

\footnotetext{
${ }^{44}$ AH III/13, k. 187.

${ }^{45} \mathrm{AH}$ III/12, k. 226.

${ }^{46} \mathrm{AH}$ III/12, k. 228.

${ }^{47}$ AH III/13, k. 186, 188.
} 
konywać „konklawe królewskie”, czyli elitarna Rada Koronna ${ }^{48}$. Odrzucał zasadę wyboru przez liczniejsze kolegium elektorskie, np. przez połączone izby parlamentu, a tym bardziej wyboru powszechnego.

Kandydować na króla mieli tylko członkowie Rady Koronnej, potem kard. Hlond dodał, że także osoby spoza wspomnianej Rady. Kandydatów spoza Rady mogli wyznaczyć tylko członkowie Rady Koronnej i to na pierwszym zebraniu wyborczym; każdy członek może wysunąć tylko 1 kandydata spoza Rady $^{49}$. Kandydat na króla musi być Polakiem i katolikiem, nie może być ożeniony z cudzoziemką (z wyjątkiem krajów będących z Polską w unii) lub Żydówką (niewątpliwie wynikało to z przekonania, że król lub królowa narodowości niepolskiej mogą reprezentować interesy sprzeczne z polską racją stanu). Kandydować na króla nie mogli także ludzie „w jakikolwiek sposób skompromitowani" ${ }^{50}$. Królem może być wybrana osoba nie mająca jeszcze skończonych 50 lat (trzeba unikać wybierania starych ludzi na króla i dlatego należy dbać o odpowiedni wiek członków Rady) ${ }^{51}$.

Elekcja króla odbywa się w stolicy najwcześniej w trzeci, najpóźniej siódmy dzień po pogrzebie króla, i przewodniczy jej marszałek Rady Koronnej Wybór króla następował: w przypadku kandydata-członka Rady większością zwykłą, w przypadku kandydata spoza Rady - większością 2/3 głosów. Król elekt obejmuje władzę z chwilą złożenia przysięgi. Składa ją wobec Rady Koronnej na ręce prymasa. Termin koronacji ustala król z uwzględnieniem okresu potrzebnego na jej przygotowanie (kilka dni po wyborze $)^{52}$. Miejscem koronacji - jak to wynika z powojennych wypowiedzi kard. Hlonda - miał pozostać Kraków, a koronatorem - prymas Polski ${ }^{53}$.

Król miał panować dożywotnio. W przypadku abdykacji miał otrzymywać emeryturę. Królowej honory królewskie przysługują tylko za życia męża. Po śmierci króla wdowa i nieletnie dzieci po królu otrzymywać będą zaopatrzenie państwowe (emeryturę). Dzieciom pary królewskiej nie przysługują jednak przywileje królewiczów. Za życia ojca-króla nie mogą zasiadać w Sejmie, Senacie, Radzie Koronnej ani być ministrami i kierować samodzielnymi placówkami dyplomatycznymi ${ }^{54}$.

IV. Bezkrólewie, regencja. Podczas bezkrólewia najwyższą władzę w państwie sprawuje nie Rada Koronna, ale jej przewodniczący - prymas

${ }^{48}$ AH III/12, k. 288; AH III/13, k. 194, 196.

${ }^{49}$ AH III/13, k. 196.

${ }^{50}$ AH III/13, k. 195; Kard. Hlond sądził nawet, że zakaz winien mieć szersze zastosowanie: „Kto ożeniony z cudzoziemką lub żydówką nie może być ani w służbie dyplomatycznej, ani ministrem, ani oficerem" (AH III/12, k. 203).

${ }^{51} \mathrm{AH}$ III/12, k. 228.

${ }^{52} \mathrm{AH} \mathrm{III/13,} \mathrm{k.} 195$.

${ }^{53}$ J. Pietrzak, Petnia prymasostwa, t. I, s. 285.

${ }^{54}$ AH III/13, k. 194. 
Polski, który jest interreksem. Wykonuje on funkcje królewskie od śmierci lub rezygnacji króla aż do wyboru i złożenia przysięgi przez następcę. Wydaje 3 manifesty: ogłasza datę i miejsce wyboru króla (ma to uczynić w dzień po pogrzebie lub ustąpieniu króla). 2) ogłasza wybór króla, 3) ogłasza datę i miejsce koronacji ${ }^{55}$. Dziwi pomysł wskrzeszenia urzędu prymasa-interreksa, istniejącego w dawnej Rzeczypospolitej, bo kard. Hlond był przeciwny sprawowaniu przez duchownych funkcji państwowych ${ }^{56}$. Zapewne od tej zasady uczynił wyjątek ze szczególnych racji historyczno-państwowych.

W przypadku, gdy król nie może dłuższy czas sprawować rządów (np. z racji choroby), Rada Koronna może wybrać regenta, określając zakres jego władzy i honorów ${ }^{57}$.

V. Rada Koronna. Pewną nowością w dotychczasowym ustroju Polski miał być organ nazwany przez kard. Hlonda początkowo Radą Państwową, potem Radą Koronną. Zdanie kardynała co do funkcji Rady zmieniało się. Początkowo określił Radę Państwową jako „najwyższy Senat Króla (...) stałe źródło informacji dla Króla i Rządu”. Potem napisał, że Rada ma obowiązek i prawo informowania króla „o życiu i to bezpośrednio, nie przez Rząd”. Ostatecznie stwierdził, że Rada Koronna jest wyłącznie ,wewnętrznym organem informacyjnym Króla” oraz „Senatem królewskim w tych sprawach, które należą do kompetencji Króla, a które Król przedłoży do zaopiniowania”. Monarcha mógł też zasięgać zdania bezpośrednio i indywidualnie u każdego członka Rady Koronnej ${ }^{58}$. W kompetencji Rady - jak już wspomniano - był wybór króla i regenta.

Rada miała odbywać regularne zebrania i nadzwyczajne „wobec króla”, prawdopodobnie więc z udziałem monarchy. Kard. Hlond początkowo przewidywał udział także premiera w posiedzeniach Rady, z czego potem zrezygnował. Posiedzenia, obrady, referaty, także wszystkie akty Rady miały być tajne ${ }^{59}$.

Radzie Koronnej przewodniczył prymas Polski. Posiadać miała także swego marszałka (kardynał wspomniał tylko o przewodniczeniu przez niego elekcji króla) ${ }^{60}$. Rada liczyć miała 24 członków, a więc była pomyślana jako organ nieliczny, elitarny. Członków Rady Koronnej mianował król. Członek Rady musiał mieć co najmniej 30 lat, nie wolno jednak było mianować osób mających ponad 50 lat. Celem zapewnienia rotacji i ,świeżości” Rady, mieli z niej ustępować członkowie z ukończeniem 65. roku życia, a także ci, którzy zasiadali w niej 20 lat. Kardynał rozważał, czy nie lepsze byłyby nomina-

${ }^{55}$ AH III/12, k. 228; AH III/13, k. 187, 195.

${ }^{56}$ J. Pietrzak, Czy kard. August Hlond był zwolennikiem sanacji?, w: Kościót w II Rzeczypospolitej. Praca zbiorowa pod red. Z. Zielińskiego i S. Wilka, Lublin 1980, s. 84-87.

${ }^{57} \mathrm{AH}$ III/13, k. 192.

${ }^{58}$ AH III/12, k. 225, 226, 228; AH III/13, k. 195, 196.

${ }^{59} \mathrm{AH}$ III/12 k. 228, 229.

${ }^{60} \mathrm{AH}$ III/12, k. 228; AH III/13, k. 195. 
cje na okres 10 lat ${ }^{61}$. Nie wiadomo, czy wspomniane rygory dotyczyły także prymasa Polski, który w tamtych czasach dożywotnio zasiadał na stolicy prymasowskiej. Być może prymas miał należeć do Rady Koronnej z urzędu. Dość liczne były wyłączenia osób, które nie mogą zasiadać w Radzie. Król nie mógł mianować do Rady ani do rządu swoich krewnych lub powinowatych w linii prostej, ani krewnych lub powinowatych aż do drugiego stopnia włącznie w linii bocznej. Nie mógł być członkiem Rady także minister, wojewoda, urzędnik państwowy, poseł, senator ani ich krewni w pierwszej i drugiej linii pokrewieństwa ${ }^{62}$.

Rada „nie ma stosunków” z Rządem, Sejmem, Senatem, co wykluczało możliwość sporów między tymi organami ${ }^{63}$. Członkowie Rady nie mogli się „mieszać do niczego" i nie mieć żadnej „funkcji” w stosunku do ministrów, Sejmu, Senatu lub jakichkolwiek urzędów państwowych i samorządowych ${ }^{64}$. Czy kard. Hlond zakładał odpowiedzialność członków Rady Koronnej - nie wiadomo.

Rada Koronna przypominała więc radę senatorów rezydentów przy królu z dawnej Rzeczypospolitej, jednak bez funkcji nadzorczych.

VI. Parlament. Przedwojenny parlamentaryzm, i to nie tylko w Polsce, kard. Hlond oceniał bardzo krytycznie. Określił go jako zdegenerowany. Twierdził, że zawierał wiele elementów „bezwstydu i upokarzającego poniżenia”. Parlament skompromitował się, upadł w opinii narodu, bo stał się wynikiem ,intryg, kłótni, funduszy wyborczych, interwencji policji, kłamstw i obrzydłości wyborczych”. Parlament „doszedł do absurdu”, bo go pojmowano i traktowano nie w ramach interesów państwa, lecz jako instytucję spod kontroli państwa wyjętą, domenę warcholstwa. Parlament swą omnipotencją skazał na niemoc państwo ${ }^{65}$.

Parlamentaryzm - uważał kard. Hlond - w dotychczasowej formie to „fałszywy dogmat polityczny" i trzeba zrewidować jego sens i zadania. Kardynał podkreślał: „Parlamentaryzm musi być instytucją na rzecz państwa (...) Parlament musi chcieć być parlamentem"66. Wahał się co do uwzględnienia polskiej tradycji parlamentarnej. W jednej notce stwierdził: „Sejmy dawnej Polski nie są kartą chlubną naszych dziejów; chorowały na niedomagania". W innej wyraził odmienną opinię: „Sejmy: jedna z najstarszych tradycji polskich, wyraz duszy i instynktu - tylko zdrowo pojęty i godnie realizowany". Ideałem wydawały mu się sejmy z czasów jagiellońskich ${ }^{67}$.

\footnotetext{
${ }^{61} \mathrm{AH} \mathrm{III/12,} \mathrm{k.} \mathrm{226,} 228$.

${ }^{62}$ AH III/12, k. 226, 229; AH III/13, k.194.

${ }^{63} \mathrm{AH}$ III/12, k. 227.

${ }^{64} \mathrm{AH}$ III/12, k. 229.

${ }^{65}$ AH III/13, k. 178, 180-182; A. Hlond, Z notatnika, s. 190.

${ }^{66} \mathrm{AH} \mathrm{III/13,} \mathrm{k.} \mathrm{182,} \mathrm{183;} \mathrm{A.} \mathrm{Hlond,} \mathrm{Z} \mathrm{notatnika,} \mathrm{s.} 300$.

${ }^{67}$ AH III/13, k. 180, 186.
} 
Notatki prymasa na temat parlamentu powojennej Polski są stosunkowo liczne, więcej dotyczą one jednak sejmu niż senatu. Kardynał opowiadał się za utrzymaniem parlamentu dwuizbowego: sejmu i senatu. Parlament ma być emanacją narodu, a nie partii, dlatego w parlamencie „nie za dużo partii”. Senat - jego zdaniem - winien być reprezentacją organizacji społecznych, „na których spoczywa struktura ekonomiczna kraju” (bliżej wspomnianych organizacji nie określił ${ }^{68}$. Co do kompetencji, uważał, że konstytucja: nie powinna (...) „odbierać odpowiedzialności Izbom”. Kompetencje izb miały jednak wynikać z potrzeb państwowych. Sejm i senat mają posiadać ,jedynie charakter legislacyjny”69. Zanotował także: „Parlament może i powinien kontrolować władzę, ale ma jej być pomocny, jako podstawa jego powagi i jako wyraz obywatelskiego ducha swych wyborców"70.

Inicjatywa ustawodawcza pochodzić miała: 1) od króla przez Radę Koronną (królewskie projekty ustaw mają charakter pierwszeństwa i pilności), 2) rządu, 3) z łona obu izb ustawodawczych ${ }^{71}$. Poseł mógłby wnieść na plenum swój projekt ustawy tylko, gdy tenże zostanie przyjęty przez wyznaczoną do tego komisję sejmową. Odnośnie do budżetu państwa rzeczą parlamentu nie jest zwiększanie wydatków, lecz ich kontrola ${ }^{72}$.

Sejm nie powinien mieć „okropnego” prawa, mianowicie „obalania rządu”. Sejm miał być „bez weta (...), bez bojkotowania spraw państwowych”. Czy kard. Hlond chciał pozbawić sejm prawa żądania ustąpienia rządu lub ministra, czy tylko osłabienia tego prawa (król mógłby takowemu żądaniu sejmu odmówić) - nie wiadomo W każdym razie parlament nie ma walczyć z rządem ani z państwem, lecz razem z rządem prowadzić państwo, nie ma przekraczać kompetencji; przeszkadzać pracy rządu, zwłaszcza wtedy gdy ten chce naprawiać błędy, usuwać nadużycia, ukracać swawolę i ograniczać ${ }^{73}$. Chodziło o ograniczenie roli parlamentu jako areny sporów partyjnych.

Parlament powinien być mniej liczny, by sprawniej i szybciej pracował ${ }^{74}$. „Wartość parlamentu nie zależy od listy jego członków ani częstotliwości i długości ich przemówień, ani »kilometrażu « posiedzeń”. Obradować ma zawsze „w trybie życiowym, nie przewlekać, bez popisów wymowy, warcholstwa, dokuczania rządowi, schlebianiu niecnotom narodu, demagogii, bez utrudnień królowi i rządowi"75.

Propozycje kard. Hlonda odnośnie do ograniczenia roli parlamentu i zmniejszenia jego liczebności szły po linii Konstytucji kwietniowej. Nato-

${ }^{68}$ AH III/12, k. 225; AH III/13, k. 178; A. Hlond, Z notatnika, s. 188.

${ }^{69}$ A. Hlond, Z notatnika, s. 300; AH III/13, k. 180, 196.

${ }^{70}$ A. Hlond, Z notatnika, s. 166.

${ }^{71}$ AH III/13, k. 196.

${ }^{72} \mathrm{AH} \mathrm{III/13,} \mathrm{k.} \mathrm{180,} 181$.

${ }^{73}$ AH III/13, k. 180; A. Hlond, Z notatnika, s. 193.

${ }^{74}$ A. Hlond, Z notatnika, s. 188 .

${ }^{75} \mathrm{AH}$ III/13, k. 180, 181. 
miast odbiegały co do składu senatu, będąc raczej odbiciem żywych w Polsce w okresie międzywojennych tendencji nadania tej izbie charakteru reprezentacji samorządów ${ }^{76}$.

Prymas miał bardzo krytyczne zdanie o wyborach przeprowadzanych zwłaszcza w okresie rządów sanacyjnych. Nie wahał się nawet wybory określić jako „,chuligańskie”. Nastąpił upadek w sposobie doboru kandydatów do parlamentu. Ustalani są oni $\mathrm{w}$ atmosferze sporów w prezydiach partii, targów obrzydliwych, racji niemoralnych, narzucania elementów nieodpowiednich. Za cenę wyboru kandydaci traktują protekcyjnie petycje, pretensje, nawet dyktat wyborców, często niekompetentnych do oceny sytuacji i ludzi. W rezultacie wybory parlamentarne stały się wyrazem ,wstrętnych i niskich współzawodnictw, zazdrości, sporów, targów, szarlataństwa, demagogii, szantażu". Stąd poczynił kilka uwag co do obostrzenia prawa wyborczego celem wykluczenia nadużyć wyborczych. Myślał o zakazach odbywania wieców wyborczych i włączania do akcji wyborczej ludzi poniżej 30 lat, ograniczeniu agitacji wyborczej do prasy, poddaniu jej kontroli cenzury, pozbawieniu biernego prawa wyborczego kandydatów do parlamentów, którzy „grzeszą" przeciwko prawu wyborczemu ${ }^{77}$. W nowej Polsce wybory miały odbywać „,bez pieniędzy, bez kiełbasy i wódki"78.

$\mathrm{Na}$ temat zasad wyboru parlamentu kard. Hlond napisał niewiele. W jednej z notatek stwierdził: „Parlament wybierany jak dotąd”. W innych: „Głosować! Oto królewski udział ludu w życiu państwowym”. Parlament ma być powoływany godnie i bez wstrząsów dla kraju ${ }^{79}$. Prawdopodobnie chodziło mu o utrzymanie zasady wyborów powszechnych do sejmu. Nie wdawał się w szczegóły sposobu wyboru posłów i senatorów. Podkreślał, że poseł na sejm reprezentuje interesy państwa, a nie swoje ani swojego obwodu, grupy lub stronnictwa. Minister, wojewoda, oficer nie może być posłem ani senatorem, bo funkcje te są częściowo nie do pogodzenia, zwłaszcza funkcja kontroli. „To odbiera Sejmowi swobodę i swobodne wtedy nie są wybory (...) To należy do złych obyczajów parlamentarnych w etyce spodlonej demokracji - bo było przeciw demokracji, czyli udziałowi narodu i ludu w życiu państwowym" $"$.

Co do odpowiedzialności posłów na sejm, ich nietykalność winna dotyczyć tylko spraw urzędu poselskiego, wystąpień i głosowań w parlamencie. Ma być większa niż ministrów w niektórych przypadkach (np. słusznej krytyki rządu i budżetu, ale nie w przypadku obrazy rządu lub zwykłych prze-

${ }^{76}$ Ankieta Konstytucyjna Sejmu R.P., „Nowe Państwo”, t. I (1931), z. 2, s. 40, 56, 78; t. II (1931), z. 3, s. 5-6, 23.

${ }^{77} \mathrm{AH}$ III/13, k. 181-183.

${ }^{78}$ A. Hlond, Z notatnika, s. 145.

${ }^{79}$ Ibidem, s. 188; AH III/13, k. 180, 183.

${ }^{80}$ AH III/12, k. 226, AH III/13, k. 181, 182; A. Hlond, Z notatnika, s. 193. 
stępstw). „Co jest karygodne w sobie lub w świetle ustaw, nie może być bezkarnie praktykowane przez posłów ani w Sejmie". Ograniczenie praw poselskich „nie jest sankcją ani karą, lecz potrzebą państwa" ${ }^{81}$.

VII. Rząd. Kard. Hlond określił rząd jako „właściwą władzę” w państwie. Myślał o rządzie mocnym, $\mathrm{z}$ wielką władzą ${ }^{82}$. Akcentował potrzebę zapewnienia rządowi ciągłości, którą uważał za zasadniczy element „wielkich postanowień i ich realizacji”. W stałości rządu upatrywał „warunek dobrej polityki i spokoju i powagi”. Podkreślał wagę autorytetu rządu, potrzebnego dla skuteczności rządów oraz obrony praw i wolności obywateli, a nawet dla chronienia powagi i całości państwa. Sądził jednak, że w konstytucji zaakcentowany musi być nie tylko autorytet rządu, ale i konieczność rządów sprawiedliwych ${ }^{83}$.

Podnosił funkcję ustawodawczą rządu. Był zdania, że inicjatywa ustawodawcza winna przede wszystkim pochodzić od rządu, bo jest on najkompetentniejszy do oceny potrzeby i kierunku ustaw. „Państwo ma dziś potrzeby pilne, którym nie odpowiada nieunikniona powolność ciała sejmowego". Chciał więc, by rząd miał funkcję ustawodawczą. „W każdym razie - napisał - nawet w rzeczach zleconych dzisiaj parlamentowi musi mieć rząd w okresach bez parlamentu władze zmieniania ustaw, gdy tego zachodzi potrzeba". Twierdził, że rząd i parlament to dualizm ${ }^{84}$. Może kardynał miał na myśli wydawanie dekretów przez rząd lub przez króla na wniosek rządu (tego typu uprawnienia prezydenta były przewidziane m.in. w Konstytucji kwietniowej).

Premier musi być centrum kierowniczym rządu, „W nim musi się myśl rządu łączyć i jednolicić" ${ }^{55}$. Minister ma rządzić, organizować, kierować, tworzyć, a nie być sekretarzem, koncepcistą, propagandzistą swego urzędu, nie popadać w biurokratyzm. Z racji zachowania powagi rządu, ministrowie nie powinni angażować się $\mathrm{w}$ rozgrywkii polityczne. „Nie miejsce dla ministrów w ulicznych demonstracjach, na wiecach nawet wyborczych". Ludzie w jakikolwiek sposób skompromitowani nie mogą być członkami rządu ${ }^{86}$. Zwracał uwagę na fundusze dyspozycyjne rządu, które jeżeli nie są kontrolowane, ,prowadzą do nadużyć, psują sumienia, korumpują ministrów i innych". Zastanawiał się, kto owe fundusze winien kontrolować ${ }^{87}$.

Przeciwny był przedwojennej sanacyjnej praktyce ,rządów pułkowników”. W nowej Polsce „politykę będzie robił rząd, nie wojsko”. Armia musi

\footnotetext{
${ }^{81}$ AH III/13, k. 169, 180, 183; A. Hlond, Z notatnika, s. 300.

${ }^{82}$ AH III/12, k. 225; AH III/13, k. 196, 242.

${ }^{83}$ A. Hlond, Z notatnika, s. 139, 172, 179-180, 301.

${ }^{84} \mathrm{AH}$ III/13, k. 181-182.

${ }^{85}$ A. Hlond, Z notatnika, s. 184

${ }^{86}$ Ibidem, s. 144, 179.

${ }^{87}$ Ibidem, s. 212.
} 
być apolityczna, także naczelny wódz ma posiadać tylko władzę wojskową, a nie polityczną. Wykluczał powtórzenie się sytuacji, zaistniałej przed wojną, że marszałek Edward Rydz-Śmigły był traktowany jako druga, po prezydencie, osoba $\mathrm{w}$ państwie ${ }^{88}$. Czy podobny sprzeciw u prymasa budził fakt łączenia w czasie wojny przez gen. Władysława Sikorskiego funkcji premiera i naczelnego wodza, tego nie wiadomo.

Liczne zapiski prymasa odnoszą się do administracji rządowej w terenie, bardzo krytykował jej funkcjonowanie przed wojną, zwłaszcza poczynania starostów i innych urzędników. Stwierdził m.in.: „Nie ma rządów bez administracji, ale może być i powinna być administracja bez biurokracji, bez nadużyć, bez kradzieży"89. Zmiany struktur administracyjnych jednak nie proponował.

Podobnie z sądownictwem. Tu najważniejszym postulatem było, aby wróciło ono do „dostojnej funkcji sumienia państwowego" ${ }^{90}$.

VIII. Państwo federacyjne. Powojenna Polska - zdaniem kard. Hlonda - powinna być połączona z ościennymi państwami między Bałtykiem a Morzem Czarnym. Myślał on przede wszystkim o Ukrainie, Białorusi i Litwie (państwa te wymienił w zapiskach). Przemawiać za tym miały względy wspólnego bezpieczeństwa zewnętrznego, zdolność przeciwstawienia się wpływom i ewentualnej agresji Niemiec i Rosji, a także - jak twierdził - dziejowa misja religijna i cywilizacyjna Polski na Wschodzie ${ }^{91}$. „Polska musi naokoło siebie skupić w formie federalistycznej, w formie unii wielkodusznej - całą plejadę państw, które inaczej zmarniałyby w swej niemocy i bezradności, a które w Polsce znajdą oparcie dla swego ducha, rozwoju i państwowości. [...] Polska, Ukraina, Białoruś, Litwa [...] są przeznaczone do wspólnych zadań - razem będzie im dobrze, na zasadzie wolności, wzajemnego szacunku i zaufania oraz współpracy - osobno będą zawsze narażone na niebezpieczeństwo". Polska winna być ośrodkiem federacji, silnym i atrakcyjnym dla sąsiednich państw, aby stanowił poniekąd naturalne „,centrum wspólnego ich życia”92.

Brał pod uwagę różne warianty związku od konfederacji i federacji po unię realną, przede wszystkim w aspekcie wspólnego lub odrębnego rządu, Sejmu, wojska i skarbu, natomiast prawa obywatelskie winny być równe, a sądownictwo „równoległe"93. Państwo federacyjne miało mieć wspólnego króla wspólnie wybieranego, mianowicie przez polską Radę Królewską z udziałem elektorów z państw będących w unii (po 3 elektorów z każdego państwa) bądź

\footnotetext{
${ }^{88}$ Ibidem, s. 182.

${ }^{89}$ Ibidem, s. 170, 176.

${ }^{90}$ Ibidem, s. 176, 191.

${ }^{91}$ Ibidem, s. 135-136, 156; AH III/13, k. 162.

${ }^{92}$ Ibidem, s. 135-137.

${ }^{93}$ Ibidem, s. 134; AH III/13, k. 200.
} 
przez wspólną Radę Królewską. Zdawał sobie sprawę, że trwałość unii musi wynikać ze wspólnoty ,zasadniczych założeń i celów politycznych, chociażby zachodziły różnice pewnych wewnętrznych form politycznych"94.

Wiosną 1941 r. z Lourdes w liście do dr Danuty Anny Drużbackiej (działaczki i publicystki katolickiej) napisał: „Idea dobrowolnej konfederacji w nowej szacie, skupiającej wielkie połacie Europy Wschodniej naokoło Korony polskiej, czyni wielkie postępy. Ale są to rzeczy nie dla tamtejszego świata, który się wyeliminował od kształtowania świata powojennego. Konieczna wielka dyskrecja" ${ }^{95}$. Czy prymas podejmował w sprawie federacji jakieś działania, choćby pośrednie, nie wiadomo. Znamienna jest jednak uwaga: „Sprawy ogólniejsze federacyjne - nie powinny odwracać uwagi od zadań politycznych wewnętrznych w państwach, zwłaszcza tych, które stają się ośrodkiem krystalizacyjnym i kierowniczym grup federacyjnych ${ }^{96}$. Zatem kard. Hlond sądził, że przede wszystkim należy skoncentrować się na zagadnieniach ustrojowych nowej Polski.

IX. Wpływ salazaryzmu. Z notatek kard. Hlonda wynika, że kreśląc wizję ustroju powojennej Polski, studiował doktrynę salazaryzmu oraz salazarowską konstytucję Portugalii z 1933 r. ${ }^{97}$ Świadczą one także o uznaniu, jakim darzył osobę i dokonania twórcy salazaryzmu, premiera Portugalii prof. Antonia de Oliveiry Salazara. Widać zbieżność poglądów, a może nawet oddziaływanie przede wszystkim co do potrzeby zbudowania silnego państwa, o wielkim i trwałym autorytecie (antidotium na osłabienie instytucji państwa dokonane przez partie i wypaczoną demokrację parlamentarną), państwa opartego na mocnym chrześcijańskim fundamencie moralnym, na rodzinie, państwa kierowanego przez elity, ale służącego i przewodzącego narodowi, państwa solidaryzmu społecznego, bez walk klasowych (korporacjonizm). W pewnej mierze wzorował władzę króla na prerogatywach prezydenta Portugalii, Radę Koronną na portugalskiej Radzie Państwowej (organ doradczy prezydenta Portugalii), skład senatu na portugalskiej Izbie Korporacyjnej. Był zwolennikiem korporacjonizmu, ale odrzucił portugalską monopartię. Z kolei Salazar, choć był zwolennikiem monarchii, nie zdecydował się na jej przywrócenie w Portugalii ${ }^{98}$.

Salazar, jego doktryna, dokonane reformy, fascynowały przed wojną wiele środowisk, zwłaszcza katolickich, w Europie, także w Polsce (w 1939 r.

${ }^{94} \mathrm{AH}$ III/13, k. 195, 200.

${ }^{95}$ A. Hlond do D.A. Drużbackiej, 29 IV 1941, AH V/30, k. 160.

${ }^{96}$ A. Hlond, Z notatnika, s. 191.

${ }^{97}$ O wpływie Salazara na poglądy Hlonda wspomniał K. Krasowski (s. 290), ale wątku nie rozwinął.

${ }^{98}$ AH III/12, k. 217-219, 225; AH III/13, k. 181; A.H. de Oliveira Marques, Historia Portugalii, Warszawa 1987, t. 2, s. 338-352; J. Bartyzel, Salazaryzm, w: Encyklopedia ,, biatych plam”, t. 16, Radom 2005, s. 84-88. 
Wydawnictwo Verbum wydało w polskim przekładzie słynną książkę Salazara Rewolucja pokojowa). Salazaryzm wydawał się skuteczną i moralną drogą rozwoju państwowego zagrożonego zarówno przez ,zdegenerowaną” demokrację, jak też totalitaryzm faszystowski i bolszewicki ${ }^{99}$.

W notatkach kard. Hlonda brak odwołań do ustroju monarchii brytyjskiej.

X. Relacja do poglądów i prac ustrojowych władz RP na emigracji. Pod wrażeniem przegranej kampanii wrześniowej 1939 r. powstało przeświadczenie o potrzebie gruntownej naprawy państwa. Zapowiedź zmian ustrojowych deklarowały polskie władze na emigracji ${ }^{100}$. Uczynił to prezydent RP Władysław Raczkiewicz w przemówieniu radiowym wygłoszonym w Paryżu 30 XI 1939 r. oraz rząd w odezwie do społeczeństwa w kraju, podpisanej przez premiera gen. Sikorskiego, z 18 XII 1939 r. Następnie podjęto na obczyźnie prace mające na celu przygotowanie nowej konstytucji. Najważniejszym ich efektem było opracowanie Zasad przyszłego ustroju państwowego Polski 21 I 1942 r., sporządzone przez Komisję Spraw Ustrojowych przy Premierze pod przewodnictwem prof. Stanisława Grabskiego. Od początku jednak zapewniano, że o wyborze nowego ustroju zdecyduje po wojnie naród. Takie zapewnienie ponowiono w deklaracji rządowej z 24 II 1942 r.: „O przyszłym ustroju politycznym i gospodarczym Państwa Polskiego zdecyduje ostatecznie Sejm Wolnej Polski, w którego ręce Rząd odda władzę ustawodawczą bezzwłocznie po zakończeniu działań wojennych". W tej materii stanowisko kard. Hlonda i władz polskich na obczyźnie było identyczne.

Zbieżność istniała także co do potrzeby oparcia ustroju nowej Polski na zasadach chrześcijańskich. Rząd na emigracji w odezwie do społeczeństwa w kraju z 18 XII 1939 r. napisał: „Nie przesądzając w niczym nowego ustroju politycznego, społecznego i gospodarczego, o którym zadecyduje kraj po odzyskaniu wolności, Rząd stwierdza: Polska będzie państwem stojącym nadal na gruncie kultury i zasad chrześcijańskich”. Rząd złożył ponownie takie zapewnienie w deklaracji z 24 II 1942 r.: „Polska stać będzie na gruncie kultury i zasad chrześcijańskich". Wcześniej także Komisja Spraw Ustrojowych przy Premierze w opracowaniu Zasady przyszlego ustroju państwowego Polski z 21 I 1942 r. napisała: „Racja stanu i dobro Narodu winny być kierowane normami etycznymi, wypływającymi z Nauki Chrystusowej”.

Co do konkretnych rozwiązań ustrojowych poglądy kard. Hlonda i władz polskich na obczyźnie były raczej różne. Prymas eksponował potrzebę odbu-

99 B. Łączkowski, Zachodnia brama świata, Warszawa 1939, s. 28-123; N.L. Cieszyński, Roczniki Katolickie na Rok Pański 1937, Poznań-Łomża 1937, s. 324-331.

${ }^{100}$ Emigracyjne pomysły i prace dotyczące przyszłej konstytucji RP i federacji z Czechosłowacją zreferowałem na podstawie książek: T. Kisielewski, Federacja środkowo-europejska. Pertraktacje polsko-czechosłowackie 1939-1943, Warszawa 1991 oraz P.K. Marszałek, Komisja Spraw Ustrojowych Grabskiego w latach 1941-1942. Dokumenty i materialy, Torun 2009. 
dowy silnego państwa, ograniczenia roli partii i parlamentarnej demokracji, zaprowadzenia monarchii, władze na emigracji - potrzebę demokratyzacji, autentyczności parlamentu i jego kontroli nad rządem, nie kwestionowały ustroju republikańskiego. Wprawdzie w Komisji Spraw Ustrojowych rozważano zalety ustroju monarchicznego, ale zdawano sobie sprawę, że pomysł przywrócenia monarchii w Polsce napotka ogromny opór polityczny i społeczny. Natomiast istniała zgodność co do potrzeby utrzymania kluczowej prerogatywy głowy państwa - swobodnego powoływania premiera. Komisja Spraw Ustrojowych jednak chciała, aby gdy rząd otrzyma wotum nieufności połączonych izb ustawodawczych, wówczas Prezydent był zobowiązany do odwołania rządu i mianowania nowego albo do rozwiązania Sejmu i rozpisania nowych wyborów. Kard. Hlond o takim przypadku nic nie napisał. Pewne podobieństwo wykazują pomysły kard. Hlonda ustanowienia Rady Koronnej przy Królu oraz Komisji Spraw Ustrojowych - ustanowienia Rady Stanu przy Prezydencie, a także zmodyfikowania składu Senatu.

Rząd na emigracji już 10 X 1939 r. uznał, że w Europie środkowej powinien powstać związek państw na czele z Polską, będący przeciwwagą dla Niemiec i Związku Sowieckiego. Zapoczątkować go miała federacja Polski i Czechosłowacji, do której planowano włączyć kolejne państwa, m.in. Litwę, Węgry, Jugosławię. Koncepcję utworzenia federacji środkowo-europejskiej popierała Wielka Brytania. Podjęto przede wszystkim rozmowy z władzami czechosłowackimi na emigracji oraz powołano Komitet Polityczny Rady Ministrów pod przewodnictwem gen. Kazimierza Sosnkowskiego, który opracował Projekt Zasad Aktu Konstytucyjnego Zwiazku Polsko-Czechostowackiego z 21 V 1941 r. Postęp negocjacji polsko-czechosłowackich utrudniały różnice co do formuły związku. W 1943 r. władze czechosłowackie na obczyźnie zawarły układ ze Związkiem Sowieckim. Stalin sprzeciwiał się utworzeniu federacji polsko-czechosłowackiej. W rezultacie rząd czechosłowacki zerwał rozmowy z rządem polskim na temat związku między obu państwami.

W Polsce przedwojennej zwolenników monarchii było niewielu i ruch monarchiczny nie miał większego znaczenia politycznego ${ }^{101}$. Jednak już w październiku 1939 r. niektórzy polscy politycy na emigracji zaczęli optować nie tylko za utworzeniem federacji środkowo-europejskiej, ale nadaniem jej monarchicznej formuły. Oficjalnie sprawę rozważano w latach 1940-1942 w gremiach rządu na emigracji, głównie na forum Komitetu Politycznego Rady Ministrów w trakcie prac nad Projektem Zasad Aktu Konstytucyjnego Zwiazku Polsko-Czechosłowackiego oraz Komisji Spraw Ustrojowych przy Premierze pracującej nad zasadami przyszłego ustroju państwowego Polski. Główną racją zaprowadzenia monarchii, i to dziedzicznej, było przekonanie, że król, zwłaszcza gdyby pochodził z dynastii panującej w Wielkiej Bryta-

${ }^{101}$ J. Pietrzak, ,, Wyjarzmiona” Polska miała być monarchia, „Gazeta Ostrowska” 7 IV 1996, nr 14. 
nii, mógłby stać się czynnikiem integrującym połączone kraje i narody oraz oparcia polityczno-militarnego federacji na imperium brytyjskim. W czerwcu 1941 r. zapewne decyzją premiera gen. Sikorskiego, który sam był zwolennikiem ustanowienia monarchii, postanowiono na razie nie forsować takiego zamiaru w rozmowach polsko-czechosłowackich, zachowując republikański charakter przyszłego związku, oraz odczekać na stosowniejszą chwilę dokonania zmiany ${ }^{102}$. Natomiast Komisja Polityczna w opracowaniu Zasady przyszłego ustroju państwowego Polski, 21 I 1942 r. opowiedziała się za ustrojem republikańskim, ale nie wykluczyła, że mogą względy polityki międzynarodowej uczynić ,,aktualnym i potrzebnym przyjęcie przez Naród Polski demokratycznego ustroju monarchicznego".

Kandydata na przyszłego króla Polski i federacji upatrywano przede wszystkim w Jerzym księciu Kentu - bracie króla angielskiego Jerzego VI. Służył on wówczas w RAF w randze marszałka lotnictwa jako oficer operacyjny. Znany był z sympatii propolskich. Zarówno on, jak i jego urocza małżonka Marina, księżniczka grecka, wnuczka króla Grecji Jerzego I, cieszyli się popularnością w kręgach polskich, zwłaszcza wśród lotników polskich, których wizytowali. Gen. Sikorski popierał jego kandydaturę. Jerzy ks. Kentu zginął w katastrofie lotniczej w Szkocji 25 VIII 1942 r. ${ }^{103}$

Koncepcja federacji Polski z Litwą, Białorusią i Ukrainą proponowana przez kard. Hlonda różniła się od federacji planowanej przez władze polskie na emigracji przede wszystkim zasięgiem terytorialnym, chociaż idea utworzenia federacji była po części zbieżna, mianowicie stworzenie przeciwwagi dla Niemiec i Rosji. Podobnie istniała więc zbieżność między kard. Hlondem a niektórymi kręgami rządowymi na emigracji dotycząca ustanowienia monarchii w Polsce, ale odmiennie uzasadniano powody takiej decyzji. Kard. Hlond podkreślał głównie racje polskie, politycy emigracyjni - przede wszystkim racje federacyjne. Różna była także koncepcja monarchii, choćby co do elekcyjności i dziedziczności tronu. Co do kandydata na tron, to kard. Hlond nigdy nie wypowiedział się w tej sprawie. Raczej trudno sobie wyobrazić, aby akceptował kandydaturę księcia Kentu, cudzoziemca, anglikanina, który - jak się okazało po śmierci - był wielkim mistrzem Zjednoczonej Wielkiej Loży Angielskiej, o czym biskup polowy WP Józef Gawlina poinformował kard. Hlonda ${ }^{104}$.

${ }^{102}$ T. Klimecki do K. Sosnkowskiego 11 VI 1941, Archiwum PAN w Poznaniu, Spuścizna Bohdana Winiarskiego, teka 5.

${ }^{103}$ K. Glabisz do J. Pietrzaka 17 XII 1975, Zbiory J. Pietrzaka; E. Winnicka, Książę Jerzy, król Polski? Stowiańskie królestwo pod flaga brytyjska, www.polityka.pl/historia/

${ }^{104}$ Korespondencja Augusta Hlonda i Józefa Gawliny w latach 1924-1948, wyd. J. Myszor i J. Konieczny, Katowice 2003, s. 232, 238, 244; J. Gawlina, Wspomnienia, oprac. J. Myszor, Katowice 2004, s. 207; T. Serwatka, op. cit., s. 129. twierdzi, że kard. Hlondowi spodobała się idea powojennej federacji Polski z Czechosłowacją, ewentualnie z brytyjskim księciem Kentu na czele. Źródło, na które się T. Serwatka powołuje (Korespondencja Augusta Hlonda i Józefa Gawliny, 
Prawdopodobnie kard. Hlond stworzył swoją wizję ustroju powojennej Polski niezależnie od prac konstytucyjnych i federacyjnych rządu na emigracji. W każdym razie prymas był informowany przez biskupa polowego Gawlinę przynajmniej o niektórych planach ustrojowych rozważanych w kręgach rządowych, m.in. pomysłach przywrócenia monarchii i utworzenia federacji z państwami ościennymi. ${ }^{105}$. Prymas po zreferowaniu mu planów prof. Grabskiego odpisał bp. Gawlinie, że są one „zasadniczo dobre” i zapowiadał, że przy okazji planowanej wizyty w Wielkiej Brytanii, gdy spotka się z prof. Grabskim „wypowiem mu swoje uwagi, bo sam ten problem szeroko przemyślałem" ${ }^{106}$. Do wizyty kard. Hlonda w Wielkiej Brytanii jednak nie doszło i nie wiadomo, czy prymas swoje propozycje ustrojowe przekazał prof. Grabskiemu inną drogą. Ważną rolę w pracach ustrojowych i federacyjnych na emigracji odgrywał także Bohdan Winiarski - przed wojną profesor prawa międzynarodowego na Uniwersytecie Poznańskim, związany dość blisko $\mathrm{z}$ kard. Hlondem. Był on jednym z promotorów nadania federacji polsko-czechosłowackiej monarchicznej formuly. Czy kard. Hlond informował prof. Winiarskiego o swoich pracach konstytucyjnych oraz czy ten z kolei informował prymasa o pracach konstytucyjnych na emigracji? Korespondencji takiej nie odnaleziono. Nie wiadomo więc, czy oba nurty prac ustrojowych prymasa i komisji rządowej oddziaływały na siebie.

XI. Motywy i znaczenie zapisków. Ks. W. Necel - wydawca notatek kard. Hlonda - napisał, że właściwie do końca nie wiadomo, dlaczego kardynał z taką konsekwencją zapisywał swoje przemyślenia ${ }^{107}$. Pytanie szczególnie należy odnieść do notatek o charakterze ustrojowo-politycznym. Prymas już przed wojną interesował się katolicką nauką o państwie oraz relacjami państwa i Kościoła. W 1931 r. jako przewodniczący Komisji Prawnej Episkopatu zredagował w sporej mierze Uwagi Episkopatu Polski w przedmiocie zmiany Konstytucji. Dokument ten przygotowano w odpowiedzi na zaproszenie sejmu do udział w ankiecie konstytucyjnej. W 1932 r. Hlond wydał głośny list pasterski $O$ chrześcijańskie zasady życia państwowego. Notatki wojenne można więc traktować jako kontynuację jego zainteresowań problematyką

op. cit.), nie daje podstaw do takiego twierdzenia, ponieważ nie zawiera opinii kard. Hlonda ani co do federacji polsko-czechosłowackiej, ani kandydatury ks. Kentu, natomiast bp Gawlina odnosił się do wspomnianej kandydatury sceptycznie.

${ }^{105}$ Korespondencja Augusta Hlonda i Józefa Gawliny, op. cit., s. 232, 238, 244, 245. K. Krasowski twierdzi, że kard. Hlond w lipcu 1941 r. przesłał do Londynu swoje pierwsze ,inicjatywy ustrojowe" (Zasady konstytucji, s. 276). Powołuje się tu na list kard. Hlonda do bp. J. Gawliny z 2 VII 1941 r., ale z korespondencji tej nie wynika jednoznacznie, że listy prymasa wystosowane do różnych osób, za pośrednictwem bp. Gawliny, dotyczyły spraw ustrojowych.

${ }^{106}$ Korespondencja Augusta Hlonda i Józefa Gawliny, op. cit., s. 245 (Hlond do Gawliny 13 II 1942).

${ }^{107}$ A. Hlond, Z zapisków, s. 400 (Posłowie). 
ustrojową ${ }^{108}$. Przed wojną jednak nie wypowiadał się ani nie snuł pomysłów konkretnych rozwiązań ustrojowych, a tym bardziej wskrzeszenia politycznej instytucji prymasa-interreksa. Niewątpliwie o zmianie zapatrywań decydowała szczególna sytuacja, w jakiej znalazła się Polska podczas wojny. W czerwcu 1941 r. zwierzył się poufnie B. Longchampsowi, że ,problem ustrojowy interesuje mnie w tej chwili nadzwyczajnie" 109 . Wprawdzie w tragicznym wrześniu 1939 r. odmówił przyjęcia propozycji objęcia urzędu premiera, którą złożył mu gen. Bolesław Wieniawa Długoszowski, wyznaczony na prezydenta Rzeczypospolitej, ale miał świadomość, że propozycja ta, jak i wcześniejszy zamysł ustanowienia go następcą prezydenta, wynikały z odrodzenia się przynajmniej w niektórych kręgach politycznych idei prymasa-interreksa ${ }^{110}$. Potem na pewno inspirowały go wieści z okupowanej Polski, że ,jakoby tam w poważnych kołach myślano o oddaniu władzy Prymasowi jako interrexowi, któryby jako centralny autorytet ustrzegł Rzeczpospolitą od rozbicia w pierwszych miesiącach [po wojnie], a zarazem przygotował konstytucje i dał Polsce króla"111. W jakich kołach snuto takie plany - nie wiadomo. Pomysł jednak nie był nowy, bo podobnie myślano w czasach zaboru ${ }^{112}$. Znamienne, że także w powojennej Polsce byli zwolennicy idei prymasa-interreksa ${ }^{113}$.

Kard. Hlond o swoich pracach konstytucyjnych informował niewielu i to poufnie ${ }^{114}$. Zachowały się tylko luźne notatki dotyczące ustroju powojennej Polski, mniej lub więcej obszernie traktujące poszczególne materie konstytucyjne. $\mathrm{Z}$ korespondencji prymasa wynika jednak, że przygotowywał na temat ustroju „zasadniczą i większą rzecz”, w innym miejscu napisał, że planuje wydanie „karty do narodu”. Do tej pory takich opracowań nie odnaleziono. Nie wiadomo więc, czy prymas z luźnych notatek nadał kształt projektu konstytucji, czy raczej poprzestał na sformułowaniu pewnych zasad ustrojowych, które zamierzał przedstawić narodowi.

Wiosną 1941 r. w liście do Klemensa Jędrzejewskiego (działacza katolickiego i harcerskiego) napisał: „A już zupełnie zbawczy i wyzwalający przewrót dokonać się musi w dziedzinie politycznej i społecznej. Inaczej wszystko to, co cierpimy, byłoby zmarnowane i jako ekspiacja, i jako krwawa siejba przyszłości. Piszę w tym względzie zasadniczą i większą rzecz, tym razem

${ }^{108}$ A. Hlond, Na straży sumienia narodu. Wybór pism i przemówień, wyd. A. Słomka, Ramsey 1951, s. 53-77; Ankieta Konstytucyjna Sejmu RP I. Uwagi Episkopatu polski w przedmiocie zmiany konstytucji, „Nowe Państwo”, t. I (1931), z. 2, s. 15-18.

${ }^{109}$ A. Hlond do B. Longchampsa 12 VIII 1941, AH IV/17, k. 15.

110 J. Pietrzak, Petnia prymasostwa, t. I, s. 284.

${ }^{111}$ A. Hlond do B. Longchampsa 12 VIII 1945, AH IV/17, k. 15-16.

112 J. Pietrzak, Senat Rzeczypospolitej Polskiej. Tradycja i współczesność XV-XXI w., Warszawa 2010, s. 123-124.

${ }^{113}$ J. Pietrzak, Petnia prymasostwa, t. I, s. 285-286.

${ }^{114}$ A. Hlond do D.A. Drużbackiej 29 IV 1941, AH V/30, k. 160; A. Hlond do B. Longchampsa 12 VIII 1945, AH IV/17, k. 15. 
z tytułu interrexa, by zaraz w dzień narodowego alleluja wskazać narodowi drogę wielkości i jasną wizję posłannictwa"115. Jeszcze dobitniej wyraził to w jednej z notatek: „to piszę jako interrex - nie jako przedstawiciel Kościoła, który się z żadną formą rządu nie łączy i nie identyfikuje, ale każdą prawowitą władzę popiera". Planował wydanie Karty interrexa do narodu z wezwaniem do stworzenia Konstytucji Zmartwychwstania, jak niegdyś Konstytucji 3 maja, ale ,pełniejszej, nowocześniejszej, lepszej”.

Zatem kard. Hlond formułował zasady i wskazówki ustrojowo-polityczno-moralne dla nowej Polski nie tyle jako hierarcha kościelny, ile jako następca dawnych prymasów-interreksów przedrozbiorowej Rzeczypospolitej. Sądził, że ma do tego nie tylko moralne prawo, ale Opatrzność da mu realną możliwość, jako prymasowi-interreksowi, kształtowania ustroju odrodzonej Rzeczypospolitej. Wprawdzie taka możliwość nie zaistniała, ale on sam stał się w powojennej, zniewolonej Polsce duchowym interreksem, proreksem (zastępcą króla), jak go nazwał złotousty arcybiskup Antoni Szlagowski ${ }^{116}$.

Projekt ustroju politycznego zarysowany przez kard. Hlonda nosił znamię czasu, w jakim powstał, okresu II wojny światowej, dążności do naprawy państwa, którego kryzysu doświadczono przed wojną oraz marzeń o nowej, lepszej Polsce. Najbardziej kontrowersyjny był pomysł zaprowadzenia monarchii „ludowej”. W powojennej Polsce, nawet gdyby miała ona swobodnie decydować o swoim ustroju, urzeczywistnienie takiego zamysłu byłoby bardzo trudne. Znamienne jednak, że kard. Hlond do zgonu, wierząc, iż doczeka się „Polski prawdziwej”, pozostał zwolennikiem ustroju monarchicznego, upatrując w nim gwarancję i symbol wielkości oraz niepodległości państwa ${ }^{117}$.

\section{PRIMATE HLOND ON THE POLITICAL SYSTEM OF POST-WAR POLAND}

\section{Summary}

Cardinal August Hlond, Primate of Poland, lived in exile in France during World War II between 1940 and 1944. At that time, he made many notes on how he saw post-war Poland, including her future political system. He was critical of both the 1921 and 1935 constitutions and above all, he disapproved of party contentious poli-

${ }^{115}$ A. Hlond do K. Jędrzejewskiego 23 IV 1941, AH V/29, k. 279.

116 J. Pietrzak, Petnia prymasostwa, t. I, s. 285-286.

${ }^{117}$ Ibidem, t. I, s. 285. K. Krasowski zakończył swój artykuł stwierdzeniem, że kard. Hlond po wojnie nie potrafił przełamać w sobie uprzedzeń wobec komunistów i dostosować się do zmienionej rzeczywistości, popadł w mistycyzm i wizjonerstwo oraz nie przypominał już dawnego dynamicznego przywódcy Kościoła w Polsce. Są to stwierdzenia i opinie bardzo kontrowersyjne, a nawet bezzasadne. Polemiki szerszej nie podejmuję, bo zagadnienie nie dotyczy tematyki artykułu. Zainteresowanych odsyłam do książki: J. Pietrzak, Petnia prymasostwa, t. I-II. 
tics and the methods of government used by the Polish pre-war regime. He saw a need to build a strong state, which would command great and lasting respect, whose political system would be based on Christian principles, which would be ruled by the elites but for the benefit of the nation, and in which social solidarity would prevail. He was in favour of a modern elective monarchy, with a strong executive, and a federation of Poland and neighbouring countries, in particular Ukraine, Belarus and Lithuania. Such a political system supposedly guaranteed the country's greatness and independence. He believed that he would be able to take part in the process of designing the political system of post-war Poland as an interrex. Cardinal Hlond's ideas on the future political system resembled in part those worked out by the circles centred around the Polish government in exile in London, drafting a new constitution for Poland.

\section{PRIMAT HLOND SUR LE RÉGIME POLITIQUE POLONAIS D'APRÈS-GUERRE}

\section{Résumé}

Durant la Seconde Guerre mondiale, le primat polonais, cardinal August Hlond, est absent de son pays, vivant en exil en France, entre autres, dans les années 1940-1944. Il rédige à l'époque de nombreuses notes concernant sa vision de Pologne après la guerre, y compris le futur régime politique du pays. Il reste critique quant à la constitution de 1921 et celle de 1935, mais il fait avant tout la critique des partis qui sèment la discorde entre eux ainsi que des méthodes de gouverner le pays, appliquées dans le cadre de la politique intérieure «d'assainissement». Hlond est convaincu qu'il faut absolument créer un État fort, jouissant d'un grand prestige de façon pérenne, dont le régime sera basé sur les règles du christianisme, État dirigé par les élites, État au service de la nation, État du solidarisme social. Il souhaite mettre en place une monarchie électivemoderne, avec un gouvernement puissant, créer une fédération entre la Pologne et les États limitrophes, notamment l'Ukraine, la Biélorussie et la Lituanie. Le régime sous cette forme-là devait garantir, selon lui, la grandeur et l'indépendance de l'État. Il croit, en outre, pouvoir influencer en qualité d'interrex le processus de formation du régime de la Pologne d'après-guerre. Les idées sur le régime du cardinal Hlond sont, en partie, proches aux travaux sur la nouvelle constitution de la Pologne, menés à l'époque par les représentants du gouvernement polonais en exil à Londres. 